Jambura Health and Sport Journal

Vol. 4, No. 1, Februari 2022

p-ISSN: 2654-718X, e-ISSN: 2656-2863

\title{
MENINGKATKAN HASIL BELAJAR MENGOPER PADA SEPAK BOLA MELALUI PENDEKATAN BERMAIN
}

\section{IMPROVING PASSING LEARNING OUTCOMES IN FOOTBALL GAMES THROUGH PLAYING APPROACHES}

\author{
${ }^{1 *}$ Ruslan, ${ }^{2}$ Moh. Rukhyat Amin \\ ${ }^{1 * 2}$ Pendidikan Jasmani Kesehatan dan Rekreasi, Fakultas Olahraga dan Kesehatan Universitas Negeri Gorontalo
}

Kontak koresponden: ruslan@ung.ac.id

\begin{abstract}
ABSTRAK
Keterampilan mengoper dalam olahraga Sepak bola merupakan sebuah keterampilan dasar yang digunakan dalam memindahkan bola dari satu pemain ke pemain yang lainnya. Penelitian ini merupakan Penelitian Tindakan Kelas (PTK) yang bertujuan untuk meningkatkan hasil belajar mengoper pada permainan Sepak bola melalui pendekatan bermain siswa Kelas XI IPA 3 di SMA Negeri 4 Gorontalo. Subjek penelitian ini adalah siswa-siswi kelas XI IPA 3 SMA Negeri 4 Gorontalo dengan jumlah 34 orang dengan masing-masing 20 orang laki-laki dan 14 orang perempuan dan merupakan penelitian populasi. Teknik pengumpulan data yang terdiri dari observasi, wawancara, dan dokumentasi. Teknik analisis data diolah dengan rumus ketuntasan belajar individu, ketuntasan belajar klasikal, dan daya serap klasikal. Hasil observasi yaitu capaian kategori sangat kurang $11.77 \%$, kurang baik $29.41 \%$, cukup baik $17.64 \%$, baik $26.47 \%$, sangat baik $14.71 \%$, kemudian dilanjutkan dengan siklus I yang mencapai kategori kurang baik $14.71 \%$, cukup baik $20.59 \%$, baik $17.64 \%$, sangat baik $47.06 \%$, kemudian hasil akhir siklus II dari penelitian ini yaitu mencapai kriteria baik $17.65 \%$ dan sangat baik $82.35 \%$ untuk kriteria ketuntasan penilaian. Pembuktian dari penelitian tersebut menyimpulkan bahwa penggunaan metode bermain yang menyenangkan telah dapat meningkatkan hasil belajar operan pada Sepak bola siswa Kelas XI IPA 3 di SMA Negeri 4 Gorontalo.
\end{abstract}

Kata Kunci: hasil belajar; mengoper; Sepak bola

\section{ABSTRACT}

Passing skills in sports Football is a basic skill used in moving the ball from one player to another. This research is a Classroom Action Research (CAR) which aims to improve the learning outcomes of passing in the soccer game through the playing approach of Class XI IPA 3 students at SMA Negeri 4 Gorontalo. The subjects of this study were students of class XI IPA 3 SMA Negeri 4 Gorontalo with a total of 34 people with 20 males and 14 females respectively and was a population study. Data collection techniques consisting of observation, interviews, and documentation. The data analysis technique was processed with the formula for individual learning mastery, classical learning mastery, and classical absorption. The results of the observation are the achievement of very poor category $11.77 \%$, not good $29.41 \%$, quite good $17.64 \%$, good $26.47 \%$, very good $14.71 \%$, then followed by cycle I which reached the category of less good $14.71 \%$, good enough $20.59 \%$, good $17.64 \%$, very good $47.06 \%$, then the final result of the second cycle of this study is that it reaches the good criteria of $17.65 \%$ and very good $82.35 \%$ for the completeness assessment criteria. The evidence from this study concludes that the use of fun playing methods has been able to improve operand learning outcomes in 
Football Class XI IPA 3 students at SMA Negeri 4 Gorontalo.

Keywords: learning outcomes; pass; Football

\section{Introduction}

If certain learning efforts provide good learning outcomes, then the process of learning activities can also be said to be efficient (Mastiyah, 2018). Teachers as educators and students as recipients of the educational process are the things that play the most role in getting optimal learning outcomes (Dai et al., 2021). Mastery of the material can be measured through success in learning through the material presented. The phenomenon that has occurred so far as a Physical Education teacher is faced with trends and vulnerable issues among the younger generation that can be obtained through grades.

The teacher's role in delivering the theme will affect students in achieving learning success (Putra, 2018; Unik Hanifah Salsabila et al., 2021). Understanding what factors students need is very important to help students achieve the best learning outcomes (Friskawati \& Sobarna, 2019). Through the teaching and learning process, the teacher serves as a driver, motivator, mentor, and provider of learning facilities for students in achieving goals (Sanjani, 2020). Physical Education teachers should not override the educational goals that surround the development of students. The development of students is the full responsibility of the teacher in knowing what is in the class related to the process of student development.

Football is a form of game consisting of two teams and each team consists of eleven players with one player as the goalkeeper / goalkeeper (Kubela \& Ritiauw, 2021). Football is a very popular game, because football games are often played by children, adults and parents (Aji, 2016). To be able to play football properly and correctly, players must master the basic skills of football (Gazali, 2016). To play ball well, players are equipped with good basic skills, players who have good basic skills tend to be able to play football well too. The basic techniques in Football games consist of several kinds, such as passing-stoping, dribbling, heading and shooting (Wardiyanto, 2019). Especially in passing skills (feeding the ball), especially under passing, players must master these skills well, because passing skills are very influential on the game of football players (Tarju \& Wahidi, 2017). Because with this skill, the game will look good and beautiful. Passing is one of the skills to feed the ball to friends in a team, the perfection of passing is very influential in determining the rhythm of the game both during defense and attack. Underpassing is the skill of passing the ball with the position of the ball's speed remaining below and its height not above the knee of the feeder or receiver.

This researcher takes the motion of passing in a Football game. Considering the importance of passing motion in Football games for students of class XI IPA 3 at SMA Negeri 4 Gorontalo. In order for the competency standards of physical education learning in the passing movement in Football games to be carried out in accordance with the guidelines, aims and objectives, as contained in the curriculum, physical education teachers must be able to design learning that is in accordance with the abilities and maturity of students and it is necessary for teachers to seek various movements that are developed towards a more attractive and 
encouraging student. For this reason, teachers must try as optimally as possible in giving birth to the forms of their activities. Without maximum effort it is impossible for athletic learning to change. In fact, it will even more polarize the boredom of students towards Football sports activities that seem monotonous so that the learning process can run smoothly. We realize that in the process of implementing Football learning, many problems arise.

\section{Method}

The subjects of this study were students of class XI IPA 3 SMA Negeri 4 Gorontalo with a total of 34 people, each 20 male and 14 female. In the implementation of this classroom action research (PTK) using several data collection techniques consisting of: Observation, is a data collection technique that is carried out by observing and recording important things that occur during the teaching and learning process. Interview, is a data collection technique that is carried out by conducting questions and answers between researchers and teachers and students with students in class. Documentation, is a technique in data collection which is done by taking pictures in the learning class. The data obtained through observation will be analyzed, based on the predetermined indicators of student success, obtained will be processed and presented in the following ways:

1. Individual Learning Mastery : $\frac{\text { score obtained }}{\text { maximum score }} x 100$

2. Classical completion power presentation: $\frac{\text { number of students who completed }}{\text { total number of students }} x 100$

3. Classical absorption: $\frac{\text { total score of participants }}{\text { whole test score }} \times 100$

The criteria for the level of success of the action are determined as follows:

Table 1. Criteria for the level of success of the action

\begin{tabular}{cl}
\hline \multicolumn{1}{c}{ Value } & Classification \\
\hline $80 \%<$ NR 100\% & very good \\
\hline $60 \%<$ NR $79 \%$ & good \\
\hline $40 \%<$ NR $69 \%$ & enough \\
\hline $20 \%<$ NR 39\% & less \\
\hline $0 \%<$ NR 19\% & very poor \\
\hline
\end{tabular}

\section{Results}

(Nurhayati, 2014)

The research that has been done is classroom action research. The researcher was assisted by colleagues. There are four stages, namely: Preparation Stage, Research Implementation Stage, Observation and Evaluation Stage and Analysis and Reflection Stage. Before conducting the research, the researcher made observations first so that the average initial data still met the completeness value or the value above from the KKM.

When conducting this research, the researcher directly conducted an interview with a physical education teacher at SMA Negeri 4 Gorontalo. Each research cycle has four stages, namely: the Preparation Stage, the Research Implementation Stage, the Observation and Evaluation Stage and the Analysis and Reflection Stage. The results of each cycle are used as a reflection to improve results that are better than the previous cycle. After conducting preliminary 
observational research, data were collected from various results of students' practice in passing in a Football game through a student play approach. From the results of initial observations, the average ability of students above KKM 73 was 14 students or $38.23 \%$, then these results indicate that the average value of students' abilities reaches $85 \%$. These results conclude that passing in a Football game through a student play approach has not yet reached the KKM. This can be seen in the student observation table in the table below.

Table 2. Description of the initial observation

\begin{tabular}{cccc}
\hline Value range & Description & Total & Percentages \\
\hline $80-100$ & Very good & 5 & $14.71 \%$ \\
\hline $60-79$ & Good & 9 & $26.47 \%$ \\
\hline $40-59$ & Fairly good & 6 & $17.64 \%$ \\
\hline $20-39$ & Not good & 10 & $29.41 \%$ \\
\hline $0-19$ & very poor & 4 & $11.77 \%$ \\
\hline & Total & $100 \%$ \\
\hline
\end{tabular}

(Nurhayati, 2014)

Based on the results in the table above, it can be concluded that the results of the initial observations in class XI IPA 3 students of SMA Negeri 4 Gorontalo obtained poor grades. Students who get very good information are 5 with a percentage of $14.71 \%$, students who get good information are 9 with a percentage of $26.47 \%$, students who get quite good are 6 with a percentage of $17.64 \%$, students who get less good are 10 students with a percentage of $29.41 \%$ and for students who get very less information totaling 4 with a percentage of $11.77 \%$.

\section{Cycle I}

There are four steps in this cycle, namely: preparation, implementation, observation and evaluation and analysis and reflection. The following is an explanation below:

\section{Action preparation}

a. Researchers and teachers apply a play approach to improve passing learning outcomes in Football games

b. Simultaneously (researchers) make lesson plans that improve learning outcomes on passing motion in Football games

c. Conduct training on learning physical education in sports and health to improve the ability of passing motion in Football games.

d. Conduct training on learning physical education, sports and health to improve passing motion skills in Football games

e. Make an observation sheet

f. Design evaluation tool

2. Action execution

The activities carried out at this stage are carrying out learning activities as prepared. 
Teaching and learning activities are adjusted to the activity plan, namely providing an explanation before starting the lesson then helping students warm up in the field. Explain in more detail about the passing motion in Football games and guide students in making each movement individually or in groups and provide assistance to students who need it. Conducting an evaluation that has previously been given an example. At the second meeting, students were given the opportunity to practice using a student play approach and after that an evaluation was carried out on students to improve students' abilities. After that students can explain the material then students are given the opportunity to perform basic techniques in passing through a play approach, after that it is evaluated on students to obtain data on student abilities.

3. Action Analysis and Reflection

Reflection is the stage where the researcher analyzes the data obtained from the previous step. The data obtained were discussed with the teacher who was then consulted with the supervisor. If the research objectives have not been achieved, then improvements are made to the actions in the next cycle.

\section{Observation and evaluation of actions}

The implementation of passing activities in Football games looks still less effective and previously the teacher only presented the material listed in K13. In accordance with the passing material in Football games and besides that, there are also many environments where students are often held football games in the afternoon but rarely involve students.

In the initial observation, it was explained that of the 34 students who scored above the KKM 73 average, there were 14 students or $41.17 \%$. While those who get a score below the average of 73 are 20 people or $58.83 \%$ and it can be concluded that the quality of the passing technique in Football games. at the stage of the first cycle, there was an increase from 34 students who scored above the KKM 73 as many as 16 people who completed or as much as $64.71 \%$ while students who got scores below the KKM 73 were 12 students or $35.29 \%$ and it can be concluded that there is starting to be an increase in the results of the learning process in passing in a Football game through a student play approach in stage I. The factor that obtained an increase was the student's skill in kicking the middle of the ball with the side of the foot and also students were able to catch the material in theory and practice that had been explained by previous researchers. The following is a table of student scores in cycle I.

Table 3. Description of cycle I

\begin{tabular}{cccc}
\hline Value range & Description & Total & Percentages \\
\hline $80-100$ & Very good & 16 & $47.06 \%$ \\
\hline $60-79$ & Good & 6 & $17.64 \%$ \\
\hline $40-59$ & Fairly good & 7 & $20.59 \%$ \\
\hline $20-39$ & Not good & 5 & $14.71 \%$ \\
\hline & Total & $100 \%$ \\
\hline
\end{tabular}

(Nurhayati, 2014) 
Based on the results of the scores in the table above, it can be concluded that the acquisition of cycle I in class XI IPA 3 SMA Negeri 4 Gorontalo is in the sufficient category. Students who are in the less category there are 5 students with a percentage of $14.71 \%$. In the fairly good category there are 7 students with a percentage of $20.59 \%$. in the good category there are 6 students with a percentage of $17.64 \%$ while 16 students are in the very good category with a percentage of $47.06 \%$. with the overall average acquisition of students in the first cycle, namely $62.16 \%$.

In the first cycle that needs to be improved are as follows: Lack of interaction between students and teachers. Lack of student understanding in understanding passing material in Football games through student play approaches. Learning media is still less effective. Lack of motivation of teachers to students. The teacher must be able to supervise every movement of the passing technique in the Football game through the student's playing approach.

Based on the results of the basic passing technique in the Football game, it shows that 16 students with a percentage of $47.06 \%$ have reached the very good category, while 6 students are still in the good category with a percentage of $17.64 \%$ and 7 students are still in the sufficient category with a percentage of $20.59 \%$ and those who are in the less category there are 5 students with a percentage of $14.71 \%$. with the average result of the first cycle reaching $62.16 \%$. These results indicate that the average value of students has not reached the indicator value of the researcher's success.

Through reflection and discussion between researchers and research partners, each aspect of the assessment will be taught more effectively in the next cycle. Moreover, based on the results of the observation sheet, it also shows that the quality of the basic passing technique in Football games using the playing approach in cycle I is not optimal. Lack of interaction between students and teachers, lack of understanding of students in understanding passing material in Football games, lack of teacher motivation to students and teachers must be able to supervise every movement of passing techniques in Football games through student play approaches.

\section{Cycle II}

At the stage of cycle II there are four steps, namely there are four steps in this cycle, namely: preparation, implementation, observation and evaluation and analysis and reflection. The following is an explanation below:

\section{Action preparation}

a. Researchers and teachers apply a play approach to improve passing learning outcomes in Football games

b. Simultaneously (researchers) make lesson plans that improve learning outcomes on passing motion in Football games

c. Conduct training on learning physical education in sports and health to improve the ability of passing motion in Football games.

d. Conduct training on learning physical education, sports and health to improve passing motion skills in Football games 
e. Make an observation sheet

f. Design evaluation tool

2. Action execution

The activities carried out at this stage are carrying out learning activities as prepared.

Teaching and learning activities are adjusted to the activity plan, namely providing an explanation before starting the lesson then helping students warm up in the field. Explain in more detail about the passing motion in Football games and guide students in making each movement individually or in groups and provide assistance to students who need it. Conducting an evaluation that has previously been given an example. At the second meeting, students were given the opportunity to practice using a student play approach and after that an evaluation was carried out on students to improve students' abilities. After that students can explain the material then students are given the opportunity to perform basic techniques in passing through a play approach, after that it is evaluated on students to obtain data on student abilities.

3. Action Analysis and Reflection

Reflection is the stage where the researcher analyzes the data obtained from the previous step. The data obtained were discussed with the teacher who was then consulted with the supervisor. If the research objectives have not been achieved, then improvements are made to the actions in the next cycle.

4. Observation and evaluation of actions

The implementation of passing activities in Football games looks still less effective and previously the teacher only presented the material listed in K13. In accordance with the passing material in Football games and besides that, there are also many environments where students are often held football games in the afternoon but rarely involve students.

Observation or re-observation is carried out by observing student activities during learning and student responses to learning basic passing techniques in Football games. Observations were made by taking data. Cycle II was carried out in four meetings. At the third meeting, the teacher conducted learning to the students. The test data in cycle II was taken at the fourth meeting, namely when the evaluation took place. All data at this stage were collected using student observation sheets. At the second cycle meeting, the average results obtained by the researchers were: $83.97 \%$, based on the explanation of the second cycle average results above, it was concluded that the quality of passing learning in Football games had reached the indicators of the success of this study. The passing ability test in the Football game through the student's playing approach was carried out at the last meeting of the second cycle.

Table 4. Description of cycle I

\begin{tabular}{cccc}
\hline Value range & Description & Total & Percentages \\
\hline $80-100$ & Very good & 28 & $82.35 \%$ \\
\hline $60-79$ & Good & 6 & $17.65 \%$ \\
\hline
\end{tabular}




\begin{tabular}{cc}
\hline Total & $100 \%$ \\
\hline
\end{tabular}

(Nurhayati, 2014)

Based on the results in the table above, it can be concluded that the results obtained in the second cycle of class XI IPA 3 SMA Negeri 4 Gorontalo were in the very good category. Students who are in the very good category there are 28 students with a percentage of $82.35 \%$ and 6 students who still get in the good category with a percentage of $17.65 \%$. by obtaining the overall average of students in cycle II, which is $83.97 \%$ with the percentage of students who have achieved success by passing the KKM by $100 \%$ so that in this cycle it is considered to have reached a success rate of $80 \%$ of all students achieving the KKM score.

The results of the basic passing technique skills in Football games showed that 28 students with a percentage above $83.97 \%$. The average percentage of students in cycle II was $100 \%$ with the average passing basic technique results in Football games of $83.97 \%$. These results indicate that the average score of students has reached the indicators of research success.

Based on the research in cycle II, the results of the basic passing technique in Football games through the approach of playing students in class XI IPA 3 SMAN 4 Gorontalo showed that the students' abilities were categorized as high. In the second cycle, the passing technique skills in Football games have made significant progress compared to the first cycle. In the second cycle the percentage of students' abilities has increased compared to the first cycle, the increase has reached the indicator of success, namely $80 \%$ of the average percentage of students' ability in Passing the Football game in cycle II is $100 \%$ with an average result of $83.97 \%$, it means that the average student has reached the expected success indicator.

Table 5. Comparison of percentage results between initial observations, cycle I and cycle II

\begin{tabular}{|c|c|c|c|c|c|c|c|}
\hline \multirow[t]{2}{*}{ Value range } & \multirow[t]{2}{*}{ Description } & \multicolumn{6}{|c|}{ Percentage } \\
\hline & & \multicolumn{2}{|c|}{ Preliminary data } & \multicolumn{2}{|c|}{ Cycle I } & \multicolumn{2}{|c|}{ Cycle II } \\
\hline $80-100$ & Very good & $14.71 \%$ & 5 & $47.06 \%$ & 16 & $82.35 \%$ & 28 \\
\hline $60-80$ & Good & $26.47 \%$ & 9 & $17.64 \%$ & 6 & $17.65 \%$ & 6 \\
\hline $40-60$ & airly $\mathrm{g}$ & $17.64 \%$ & 6 & $20.59 \%$ & 7 & - & - \\
\hline $20-40$ & & $29.41 \%$ & 10 & $14.71 \%$ & 5 & - & - \\
\hline $0-20$ & very poor & $11.77 \%$ & 4 & - & - & & \\
\hline \multicolumn{2}{|l|}{ Average score } & \multicolumn{2}{|c|}{53.78} & \multicolumn{2}{|c|}{62.16} & \multicolumn{2}{|c|}{83.97} \\
\hline \multicolumn{4}{|l|}{ The difference in } & .38 & & \multicolumn{2}{|l|}{21.81} \\
\hline
\end{tabular}

(Nurhayati, 2014)

\section{Discussion}

The results showed that the student's playing approach could improve the technique of the Football game if it was done properly and correctly. This is in line with research which explains that the approach to playing in the sport of Football will be able to improve the basic techniques of the perpetrators (Nasution \& Suharjana, 2015; Suwignyo \& Utomo, 2021). Student skills increase because students are more active in learning and the growth of confidence and enthusiasm in their play groups. What is more visible is cohesiveness and cooperation to 
understand passing techniques in Football games through an approach to playing to solve difficulties together. Students must take their own initiative, observe, analyze and assist with assessments and so on. The function of the teacher as a facilitator or mentor is in accordance with the principles of learning and activeness in the teaching and learning process.

The results of this study prove that passing in a Football game through the student's play approach really helps foster a spirit of motivation for students to further improve their passing technique skills in a Football game through a play approach. Teachers must convince and as a source of motivation for students (Friskawati \& Sobarna, 2019; Mayanto et al., 2020), that learning and effectively and seriously can affect student success in terms of the extent to which students can take advantage of the time given and the seriousness of students in participating in training, both during PJOK lessons and when given extracurricular activities.

\section{Conclusion}

The results showed that through a playing approach students could improve their passing technique in a Football game by using various techniques correctly. Student skills increase because students are actively learning and grow self-confidence and enthusiasm in their playing groups and students are more compact and cooperative to understand passing techniques in Football games. The various functions of teachers as facilitators or mentors are in accordance with the principles of learning with activeness in the teaching and learning process.

\section{Reference}

Aji, R. B. (2016). Sepak Bola dan Eksistensi Bangsa Dalam Olimpiade Masa Orde Lama (19451966). MOZAIK HUMANIORA.

Dai, A., Hadjarati, H., \& Haryanto, A. I. (2021). Gaya resiprokal untuk meningkatkan keterampilan shooting bola basket. Altius: Jurnal Ilmu Olahraga Dan Kesehatan, 10(1), 53-65. https://doi.org/http://dx.doi.org/10.36706/altius.v10i1.14056

Friskawati, G. F., \& Sobarna, A. (2019). Faktor Internal Pencapaian Hasil Belajar Pendidikan Jasmani pada Siswa SMK. Jurnal Penelitian Pendidikan, 18(3). https://doi.org/10.17509/jpp.v18i3.15004

Gazali, N. (2016). Pengaruh Metode Kooperatif dan Komando Terhadap Keterampilan Teknik Dasar Bermain Sepakbola. JOURNAL SPORT AREA, I(1). https://doi.org/10.30814/sportarea.v1i1.373

Kubela, A., \& Ritiauw, P. P. (2021). Meningkatkan Hasil Belajar Menggiring dalam Permainan Sepakbola Melalui Metode Latihan Pada Siswa Kelas VIII C SMP Yos Sudarso Dobo. JARGARIA SPRINT: Journal Science of Sport and Health, 2(1). https://doi.org/10.30598/jargariasprintvol2issue1page40-45

Mastiyah, S. (2018). Analisis Strategi Pembelajaran Sains Dengan Perspektif Psikologi Perkembangan Peserta Didik Kelas V Pada Buku Tematik Tema 8 Sub Tema 3 Memelihara Ekosistem. E- Jurnal Mitra Pendidikan, Vol 2 No 4 (2018): Jurnal Mitra Pendidikan Edisi April. 
Mayanto, A., Zulfikar, Z., \& Faisal, A. (2020). Pengaruh Metode Pembelajaran Dan Gaya Kognitif Terhadap Motivasi Dan Hasil Belajar Penjas. Jurnal Ilmiah KONTEKSTUAL. https://doi.org/10.46772/kontekstual.v2i01.251

Nasution, I. E., \& Suharjana, S. (2015). Pengembangan Model Latihan Sepak Bola Berbasis Kelincahan Dengan Pendekatan Bermain. Jurnal Keolahragaan, 3(2). https://doi.org/10.21831/jk.v3i2.6241

Nurhayati. (2014). Meningkatkan Hasil Belajar Siswa Dengan Menggunakan Metode Bimbingan Mata Pelajaran IPA di Kelas III SD Inpres 1 Bainaa. Jurnal Kreatif Tadulako Online, 4(10).

Putra, P. (2018). Implementasi Pendidikan Karakter Dalam Pembelajaran Aqidah Akhlak (Studi Multi Kasus di MIN Sekuduk dan MIN Pemangkat Kabupaten Sambas). Al-Bidayah: Jurnal Pendidikan Dasar Islam, 9(2). https://doi.org/10.14421/al-bidayah.v9i2.14

Sanjani, M. A. (2020). Tugas Dan Peranan Guru Dalam Proses Peningkatan Belajar Mengajar. Serunai : Jurnal Ilmiah Ilmu Pendidikan, 6(1). https://doi.org/10.37755/sjip.v6i1.287

Suwignyo, H., \& Utomo, A. W. B. (2021). Pendekatan model role play dalam upaya meningkatkan hasil belajar teknik passing sepak bola. Altius: Jurnal Ilmu Olahraga Dan Kesehatan, 10(1). https://doi.org/10.36706/altius.v10i1.14135

Tarju, T., \& Wahidi, R. (2017). Pengaruh Metode Latihan Terhadap Peningkatan Passing Dalam Permainan Sepak Bola. JUARA: Jurnal Olahraga, 2(2). https://doi.org/10.33222/juara.v2i2.35

Unik Hanifah Salsabila, Risma Rahma Wati, Siti Masturoh, \& Anisa Nur Rohmah. (2021). Peran Teknologi Pendidikan Dalam Internalisasi Nilai-Nilai Pendidikan Islam Di Masa Pandemi. Jurnal Pendidikan Indonesia, 2(1). https://doi.org/10.36418/japendi.v2i1.71

Wardiyanto, Y. (2019). Perbedaan Pengaruh Model Pembelajaran Dan Kemampuan Gerak Terhadap Keterampilan Teknik Dasar Sepakbola. Sains Olahraga: Jurnal Ilmiah Ilmu Keolahragaan, 3(2). https://doi.org/10.24114/so.v3i2.15198 